\title{
Az autoimmun thyreoiditis, a kétoldali papillaris pajzsmirigy-carcinoma, a nyaki thyreolipoma és a diabetes mellitus együttes előfordulása
}

\author{
Steiner Tamás dr. ${ }^{1,2}$ - Péter Ilona $\mathrm{dr}^{4}{ }^{4}$ - Pogány Péter $\mathrm{dr} .^{3}$ \\ Lantos András dr. ${ }^{4}$. Sándor Zsuzsa dr. ${ }^{4}$ \\ Téglás Melinda dr. ${ }^{5}$ - Koltai Pál $\mathrm{dr}^{6}{ }^{6}$
${ }^{1}$ Szent János Kórház és Észak-budai Egyesített Kórházak, II. Belgyógyászat-Diabetológia Osztály, Budapest ${ }^{2}$ ARTMEDX Egészségügyi Szolgáltató Kft., Endokrinológia Szakrendelés, Budapest ${ }^{3}$ MEDSERV Egészségügyi és Szolgáltató $\mathrm{Kft}$., Budapest Országos Onkológiai Intézet, ${ }^{4}$ Daganatpatológiai Központ, Sebészeti és Molekuláris Patológiai Osztály, ${ }^{5}$ Nukleáris Medicina Osztály, ${ }^{6} \mathrm{Fej}$-Nyak Sebészeti Osztály, Budapest

\begin{abstract}
A thyreolipoma, vagy pajzsmirigy-adenolipoma a pajzsmirigy-adenoma egy extrém ritka formája, mely kötőszövetes tokkal borított érett zsírszövetet és folliculusokat is tartalmaz. Az 52 éves női cukorbetegünk növekvő nyaki teriméjének esetét mutatjuk be, mely totális thyreoidectomia során eltávolításra került. A pajzsmirigy hisztopatológiai vizsgálata autoimmun thyreoiditist, kétoldali papillaris carcinomát és lefüződött nyaki thyreolipomát igazolt. Orv Hetil. 2018; 159(25): 1024-1032.
\end{abstract}

Kulcsszavak: adenolipoma, thyreolipoma, autoimmun thyreoiditis, papillaris pajzsmirigy-carcinoma, thyreoidectomia

\section{Combined presentation of autoimmune thyroiditis, bilateral papillary thyroid carcinoma, cervical thyrolipoma and diabetes mellitus}

\begin{abstract}
Thyrolipoma or thyroid adenolipoma is an extremely rare form of thyroid adenoma, which also contains mature adipose tissue and follicles covered with fibrous capsule. We present the case of the growing cervical lesion of a 52 -yearold female with diabetes, which was removed during total thyreoidectomy. Autoimmune thyroiditis, bilateral papillary carcinoma and cervical thyrolipoma have been identified by the histopathological examination of the thyroid gland.
\end{abstract}

Keywords: adenolipoma, thyrolipoma, autoimmune thyroiditis, papillary thyroid carcinoma, thyroidectomy

Steiner T, Péter I, Pogány P, Lantos A, Sándor Zs, Téglás M, Koltai P. [Combined presentation of autoimmune thyroiditis, bilateral papillary thyroid carcinoma, cervical thyrolipoma and diabetes mellitus]. Orv Hetil. 2018; 159(25): 1024-1032.

(Beérkezett: 2017. december 8.; elfogadva: 2018. január 8.)

\section{Rövidítések}

Anti-TPO = thyreoidea-peroxidáz-ellenes antitest; CT $=$ komputertomográfia; FISH = fluoreszcens in situ hibridizáció; FNA $=($ fine-needle aspiration $)$ vékonytü-biopszia; $\mathrm{HE}=$ hematoxilin-eozin; $\mathrm{HU}=$ (Hounsfield unit) Hounsfield-egység vagy CT-szám; M.e. = mértékegység; $\mathrm{MITO}=$ mitokondriális antigén; MRI = (magnetic resonance imaging) mágnesesrezonancia-vizsgálat; PI3K = foszfatidil-inozitol-3-kináz; TPO = thyreoidea-peroxidáz 
Zsírszövet számos mirigyes szervünkben található, úgymint a mellékpajzsmirigyben, a nyálmirigyekben, az emlőben, a hasnyálmirigyben és a thymusban. Zsírtartalmú elváltozásokat a pajzsmirigyben rendkívül ritkán lehet találni, az irodalomban csak néhány esetról számolnak be. Érett zsírsejtet alkalmanként a normálpajzsmirigy perivascularis, subcapsularis régióiban és kötőszöveti septumaiban látni $[1,2]$. A pajzsmirigyben észlelt különböző zsírtartalmú elváltozások számos differenciáldiagnosztikai nehézséget vetnek fel. Az alábbi kórképeket kell elkülönítenünk: lipid-rich (lipidgazdag) adenoma, lipomato- sis, amyloid struma, pajzsmirigy-atrophia, lymphocytás thyreoiditis, Graves-kór, adenolipoma, follicularis adenoma, hyperplasticus pajzsmirigy, enkapszulált papillaris carcinoma, liposarcoma, pajzsmirigyen belül elhelyezkedő thymus vagy mellékpajzsmirigy-lipoma [3-5]. Közleményünkben egy 52 éves hypothyreosisos női cukorbeteget mutatunk be, akinek nyaki növekvő teriméje és pajzsmirigyének mindkét lebenye sebészi eltávolításra került. Teóriánk szerint a hisztopatológiai vizsgálata során talált nyaki thyreolipoma a jobb pajzsmirigy lebenyéről füződhetett le, miközben pajzsmirigylebenyeiben

1. táblázat | Laboratóriumi eredmények

\begin{tabular}{|c|c|c|c|c|c|}
\hline Laboratóriumi paraméterek & Érték & M.e. & Eltérés & \multicolumn{2}{|c|}{ Referenciaértékek } \\
\hline Süllyedés & 8 & $\mathrm{~mm} / \mathrm{h}$ & & 3 & 21 \\
\hline Fehérvérsejt & 8,02 & $\mathrm{G} / 1$ & & 4,4 & 11,3 \\
\hline Hemoglobin & 145 & $\mathrm{~g} / 1$ & & 123 & 153 \\
\hline Hematokrit & 0,429 & $1 / 1$ & & 0,350 & 0,470 \\
\hline Thrombocyta & 202 & $\mathrm{G} / 1$ & & 150 & 450 \\
\hline Vizeletfehérje & $\mathrm{Neg}$ & $\mathrm{g} / 1$ & & - & - \\
\hline Vizeletcukor & $>27,8$ & $\mathrm{mmol} / \mathrm{l}$ & +++ & - & - \\
\hline Vizeletaceton & Neg & $\mathrm{mmol} / \mathrm{l}$ & & - & - \\
\hline Vércukor & 9,6 & $\mathrm{mmol} / \mathrm{l}$ & + & 3,8 & 6 \\
\hline Kreatinin & 62 & umol/1 & & 49 & 90 \\
\hline eGFR & $>90$ & $\mathrm{ml} /$ perc $/ 1,73 \mathrm{~m}^{2}$ & & 90 & 999 \\
\hline Húgysav & 335 & $\mathrm{umol} / \mathrm{l}$ & & 155 & 357 \\
\hline Nátrium & 140 & $\mathrm{mmol} / \mathrm{l}$ & & 134 & 146 \\
\hline Kálium & 4,4 & $\mathrm{mmol} / \mathrm{l}$ & & 3,5 & 5,1 \\
\hline Kalcium & 2,33 & $\mathrm{mmol} / \mathrm{l}$ & & 2,15 & 2,60 \\
\hline Anorganikus foszfát & 1,30 & $\mathrm{mmol} / \mathrm{l}$ & & 0,81 & 1,45 \\
\hline Magnézium & 0,77 & $\mathrm{mmol} / \mathrm{l}$ & & 0,77 & 1,03 \\
\hline Gamma-GT & 25 & $\mathrm{U} / 1$ & & 5 & 38 \\
\hline Alkalikus foszfatáz & 44 & $\mathrm{U} / 1$ & & 30 & 120 \\
\hline GPT (ALAT) & 30 & $\mathrm{U} / 1$ & & 3 & 35 \\
\hline GOT (ASAT) & 24 & $\mathrm{U} / 1$ & & 3 & 35 \\
\hline Vas & 8,9 & umol/1 & - & 10,7 & 32,2 \\
\hline Teljes vaskötő kapacitás & 73,8 & $\mathrm{umol} / \mathrm{l}$ & + & 27,8 & 63,6 \\
\hline Összfehérje & 74 & $\mathrm{~g} / 1$ & & 66 & 83 \\
\hline Albumin & 47 & $\mathrm{~g} / \mathrm{l}$ & & 35 & 52 \\
\hline Koleszterin & 3,9 & $\mathrm{mmol} / \mathrm{l}$ & & 2,6 & 5,2 \\
\hline Triglicerid & 5,04 & $\mathrm{mmol} / \mathrm{l}$ & ++ & 0,70 & 2,25 \\
\hline HDL-koleszterin & 0,57 & $\mathrm{mmol} / \mathrm{l}$ & - & 1,30 & 3,80 \\
\hline T4 szabad frakció & 17,060 & $\mathrm{pmol} / \mathrm{l}$ & & 11,500 & 22,700 \\
\hline T3 szabad frakció & 4,330 & $\mathrm{pmol} / \mathrm{l}$ & & 3,500 & 6,500 \\
\hline TSH (szuperszenzitív meghatározás) & 2,810 & $\mathrm{mIU} / 1$ & & 0,550 & 4,780 \\
\hline anti-TPO & 545,00 & $\mathrm{IU} / \mathrm{ml}$ & + & 0,00 & 60,00 \\
\hline Tireoglobulin-autoantitest (ATG) & 22,00 & $\mathrm{IU} / \mathrm{ml}$ & & 0,00 & 60,00 \\
\hline TSH-receptor-autoantitest (TRAK) & $<0,30$ & $\mathrm{U} / 1$ & & 0,00 & 1,75 \\
\hline Hemoglobin AlC & 6,9 & $\%$ & + & 4,0 & 6,0 \\
\hline
\end{tabular}


Hashimoto-thyreoiditis talaján kétoldali papillaris carcinoma fejlődött ki.

Az esetünkben bemutatásra kerülő thyreolipoma mellett egyes közlemények adenolipoma és pajzsmirigy-hamartoma terminológiát használnak [6].

\section{Esetismertetés}

$\mathrm{Az} 52$ éves nóbetegünk anamnézisében sectio cesarea, nőgyógyászati beavatkozás, kétoldali kéztőalagút-szindróma miatti csuklómútét, hypertonia, gestatiós diabetes mellitus, szülése után szubsztituált hypothyreosis és hypertriglyceridaemia miatt három alkalommal lezajlott acut pancreatitis szerepel. 38 éves kora óta orális antidiabetikus és intenzív konzervatív inzulinkezelésre szorul, rendszeres diabetológiai gondozás alatt áll.

Endokrinológiai szakrendelésünkön nyaki fojtogató és gombócérzés, fáradékonyság, száraz bőr, körömberepedés, aluszékonyság, hízás, alsó végtagi ödémák miatt jelentkezett. Az ülőmunkát, főként könyvelést végző aegrota statusából kiemelendő mindkét pajzsmirigylebeny megnagyobbodása és a jobb lebeny kifejezett göbös tapintata. Testtömegindexe emelkedett $\left(34,9 \mathrm{~kg} / \mathrm{m}^{2}\right)$, vérnyomása magas (154/93 Hgmm) volt. Az alábbi gyógyszeres kezelésben részesült: naponta $267 \mathrm{mg}$ fenofibrát, $2000 \mathrm{mg}$ metformin, $100 \mathrm{ugr}$ levotiroxin, $300 \mathrm{mg}$ irbezartán, 12,5 mg hidroklorotiazid, 2,5 mg bizoprolol, 10 $\mathrm{mg}$ amlodipin, $20 \mathrm{mg}$ famotidin, $10 \mathrm{mg}$ empagliflozin, $95 \mathrm{E}$ aszpart és $60 \mathrm{E}$ glargin inzulin. A levotiroxinkezelés mellett euthyreoticus állapotban volt.

Laboratóriumi leleteit az 1. táblázat foglalja össze. Kiemelendő a thyreoidea-peroxidáz-ellenes antitest (antiTPO) emelkedett szintje, a hyperglykaemia, a glycosuria, a hypertriglyceridaemia és a sideropenia. A pajzsmirigy ultrahangos vizsgálata során inhomogén szerkezetú lebenyeket, bal oldalon egy 5 , jobb oldalon egy 6 mm-es izoechogén göböt verifikáltak. Ezenkívül a jobb lebeny közvetlen alsó széle mellett, a jugulum szintje alá nyúló, kb. $27 \times 17 \times 38$ mm-es inhomogén, vegyes echogenitású képletet figyeltek meg. A trachea nem volt diszlokált és komprimált. Nyirokcsomó-megnagyobbodást nem lehetett látni. Véleményként fogalmazták meg, hogy a jobb lebeny alsó régiójának közvetlen széle mellett látott képletnek a pajzsmirigy lebenyével való összefüggése ultrahanggal nem határozható meg pontosan, ezért tisztázására izotóp- és citológiai vizsgálat elvégzése javasolt.

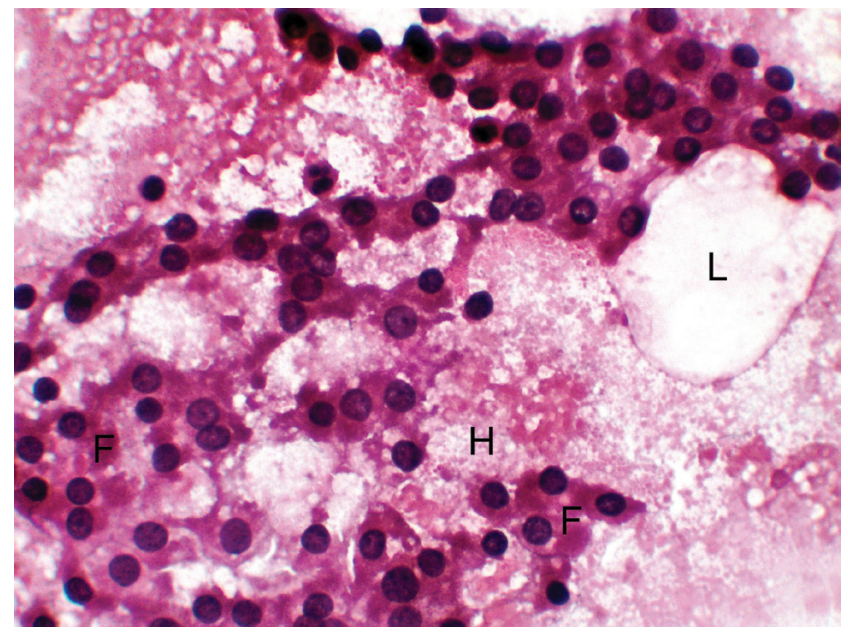

1. ábra

Ultrahangvezérelt aspirációs finomtű-mintavétel során nyert ke net mikroszkópos képe. Eozinofil festődésű, habos háttérbe $(\mathrm{H})$ ágyazottan szabályos follicularis hámsejtek (F) mellett egy kioldódott zsírcseppnek megfeleltethető, optikailag üres terület (L) figyelhető meg $(\mathrm{HE}, \times 200)$

A beteggel a levotiroxint kihagyatva, elvégeztettük a pajzsmirigy-szcintigráfiát, mely normálhelyzetú és -nagyságú pajzsmirigyet és kissé inhomogén radiofarmakoneloszlást mutatott. Nagyobb göb funkcionálisan nem különült el, és az ultrahanggal kimutatott, jobb lebeny alatt elhelyezkedő képlet a szcintigráfián nem ábrázolódott. Mellékpajzsmirigy-technécium- és MIBI-felvételek sem találtak hyperplasiára, illetve adenomára típusos körülírt kóros radiofarmakongyülemet.

Az ultrahangos kolléga javaslatát követve a jobb pajzsmirigylebeny alsó régiója melletti teriméből vékonytüaspirációs citológiai (FNA-) vizsgálat történt, mely a nyert minta sejtszegénysége miatt nem volt diagnosztikus értékü, bár felvetődött, hogy a véres keneten kívül follicularis hámsejt is található a mintában, ezért a terime pajzsmirigyszövetnek felelhet meg. Más intézményben az ugyanezen tisztázatlan képletből megismételt FNAvizsgálat a hematoxilin-eozin (HE)-festett kenetekben bőséges mennyiségű halvány eozinofil festődésû, részben habos megjelenésű kolloidszerű anyagba ágyazottan, csupasz sejtmagok mellett, egy-egy a látótérben kisebb lemezek formájában elhelyezkedően thyreocytáknak megfelelő sejtpopulációt látott. Atípia és malignitás nem volt észlelhető. Véleményként elsősorban lefüződött strumagöb lehetősége merült fel (1.ábra).

2. táblázat |Az alkalmazott antitestek listája

\begin{tabular}{|c|c|c|}
\hline Antitest (klón, eredet) & Származás / Forgalmazó & Hígítás \\
\hline CK19 (RCKl08, egér) & Dako A/S / Glostrup, Dánia & $1: 100$ \\
\hline CD56 (BC56C04, egér) & Biocare Medical / Concord, CA, Amerikai Egyesült Államok & $1: 50$ \\
\hline MITO (113-1, egér) & BioGenex / San Ramon, CA, Amerikai Egyesült Államok & $1: 50$ \\
\hline Thyreoidea-peroxidáz (MoAb47, egér) & Dako A/S / Glostrup, Dánia & $1: 100$ \\
\hline S100-protein (policlonalis, nyúl) & Dako A/S / Glostrup, Dánia & $1: 4000$ \\
\hline Ki67 (MIB1, egér) & Dako A/S / Glostrup, Dánia & $1: 100$ \\
\hline
\end{tabular}


Mindeközben a beteg nyaki szorítása, köhögése fokozódott, ezért az Országos Onkológiai Intézet Fej-Nyak Sebészeti Osztályán teljes egészében eltávolításra került a pajzsmirigyszövettel és vékony kötőszöveti tokkal határolt jobb oldali, dudorzatos sima felszínű, $40 \times 35 \times 22$ mm-es sárgásszürke paratrachealis terime. Mütét alatt fagyasztásos szövettani vizsgálatra került a jobb oldali eltávolított, $35 \times 20 \times 18 \mathrm{~mm}$-es pajzsmirigylebeny. Szklerotizáló papillaris carcinomát találva, totális thyreoidectomia történt.

A mútéti preparátumok a szokásos, formalinban történt fixálást követően kerültek feldolgozásra. A paraffinba ágyazott blokkokból 4-5 mikron vastag metszeteken HE-festés történt. A paratrachealis terime metszéslapjain az elváltozás homogén, zsírfényú, vajsárga, centrálisan 1 mm-es szürkésfehér nodulusok voltak láthatók. Hisztológiai vizsgálata zsírszövetbe ágyazva, szigetekben folliculusokból felépülő mirigyes állományt és körülötte chronicus lymphoid beszưrődést, valamint nagyszámú reaktív nyiroktüszőt verifikált. A szöveti antigének kimutatása Ventana BenchMark ultraautomata immunfestő géppel (Roche Diagnostics International Ltd., Rotkreuz, Switzerland) torma-peroxidáz indirekt immunhisztokémiai módszerrel történt. A daganatok fenotípusos jellegzetességeinek megismerése céljából a 2. táblázatban feltüntetett antitestek kerültek alkalmazásra. A vizsgálat során a folliculushámsejtekben pozitív festődést kaptunk a thyreoidea-peroxidáz (TPO), a CD56 és a mitokondriális antigén (MITO) kimutatásakor. A Ki67 a folliculusokat bélelő hámsejtekben szórványos nukleáris reakciót adott, míg a lymphoid szövetben a szokásos eloszlású és intenzitású nukleáris pozitív festődés volt látható. Mikroszkópos diagnózisként adenolipoma chronicus lymphocytás thyreoiditis jeleivel volt felállítható. Az elváltozás feltehetőleg a pajzsmirigy jobb oldali lebenyéből lefüződött nodus talaján alakulhatott ki (2. ábra).

Az eltávolított jobb pajzsmirigylebeny egygócú nem enkapszulált $12 \times 13 \times 5 \mathrm{~mm}$-es daganata papillaris carcinomának (szklerotizáló típusnak) felelt meg. A daganat nem infiltrálta a pajzsmirigy tokját. A környező pajzsmirigyállományban struma colloides hyperplastica, valamint nodularis thyreoiditis chronica lymphoida sec Hashimoto volt diagnosztizálható (3. ábra).

A mútét során a pajzsmirigy bal oldali $38 \times 33 \times 21$ mm-es lebenye is eltávolításra került. A metszéslapokat vizsgálva, benne egy $4 \times 3 \times 3 \mathrm{~mm}$-es szürkésfehér, tömött tapintatú, a reszekciós felszínt pontszerúen elérő elváltozást találtak. Mikroszkópos leírása során papillaris carcinomát véleményeztek, mely egygócú microcarcinomát, fokozott fibroplasia jeleit, nem enkapszulált, a környező pajzsmirigybe invazívan terjedő daganat képét mutatta. A környező pajzsmirigy szövettana: struma colloides hyperplastica, amelyhez thyreoiditis chronica lymphoida sec Hashimoto társult, részben nodularis formája, hegesedés, fokális ossificatio jeleivel (4. ábra).

A thyreolipoma molekuláris patológiai vizsgálata során az egész daganatos terület áttekintésre került, 50 sejt

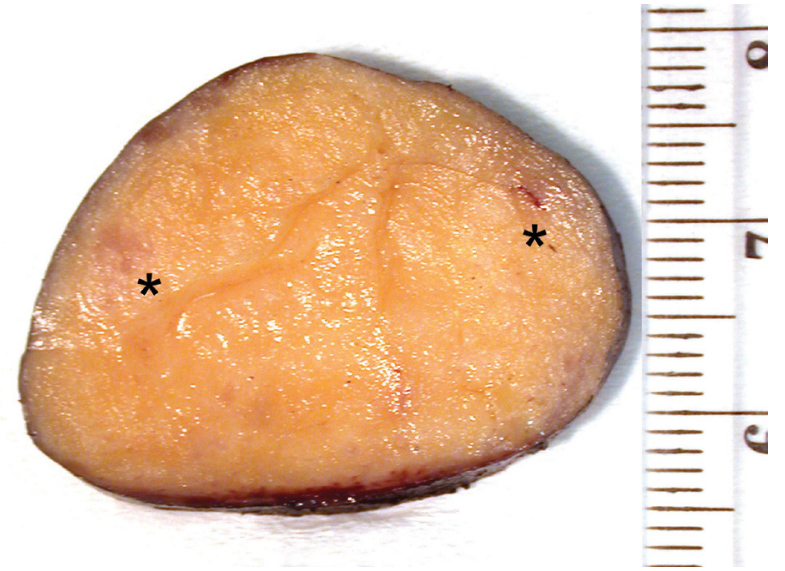

2/A ábra $\quad$ Nyaki thyreolipoma. A daganat makroszkópos képe. A metszéslapon sárga zsírfényú alapállományban elszórtan apró follicula ris-lymphocytás gócok tünnek szembe (csillag)

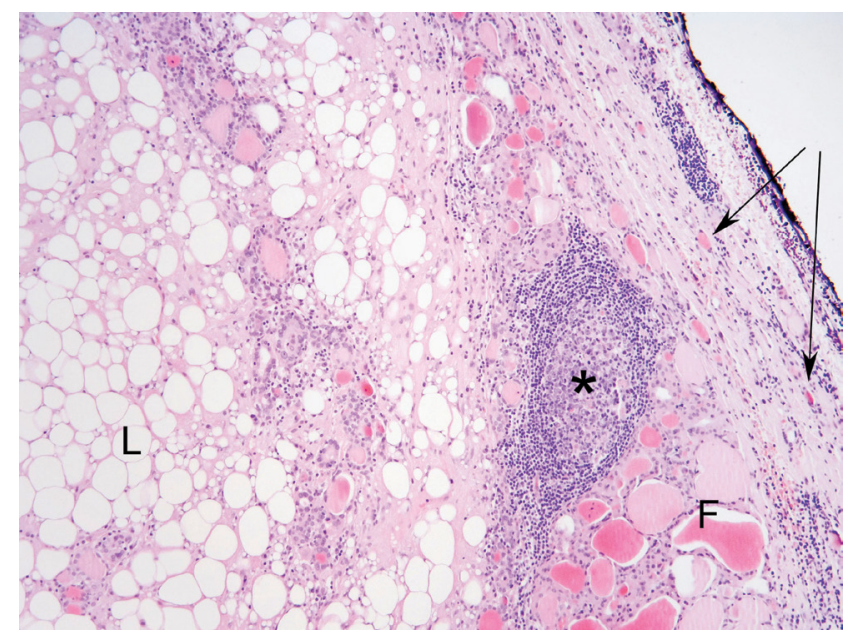

2/B ábra

Nyaki thyreolipoma mikroszkópos képe. A dominálóan zsírsejtekből felépülő daganatban kis gócban néhány folliculus (F), lymphoid beszürődés és nyiroktüsző (csillag) látható. A fekete festékkel jelölt sebészi szélnél vékony kötőszöveti tok (nyíl) rajzolódik ki $(\mathrm{HE}, \times 100)$

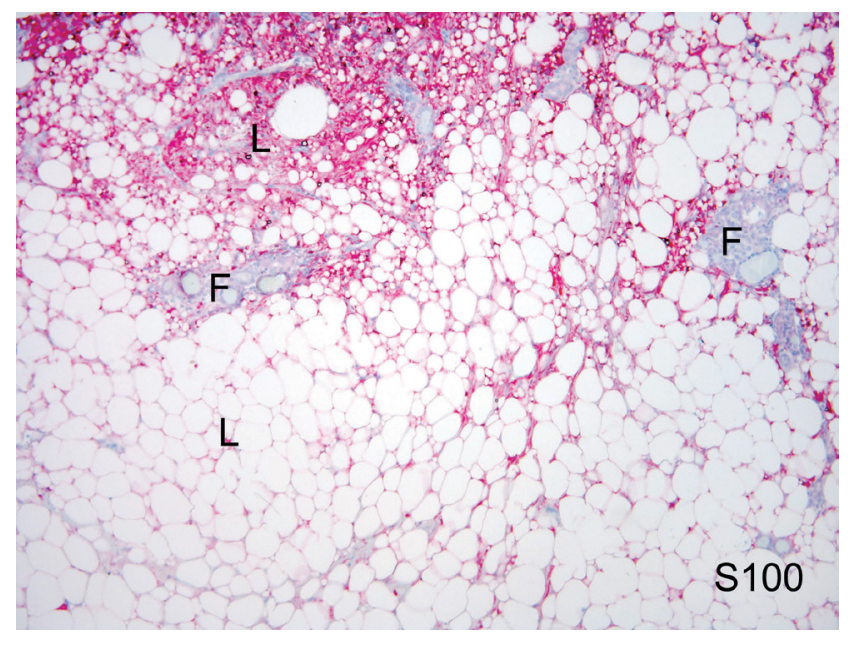

2/C ábra |A zsírsejtekben (L) kimutatható S100-protein pozitív festődését a barnásvörös reakciótermék jelzi. A folliculusokat bélelő hámsejtek (F) nem festődtek (indirekt immunhisztokémia, hematoxilin-magfestés, $\times 100$ ) 


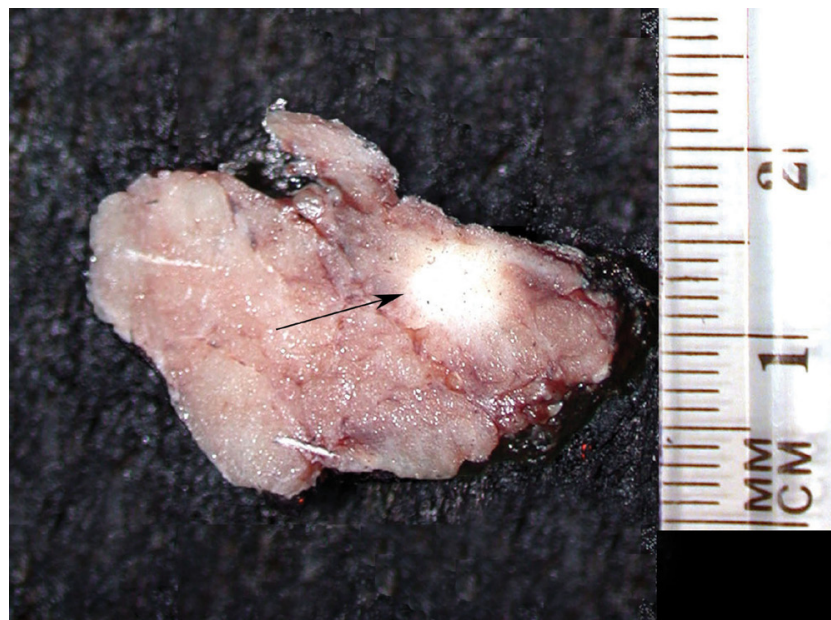

3/A ábra A pajzsmirigy eltávolított jobb oldali lebenyének makroszkópos képe. A metszéslapon élesen el nem határolódó tumor különül el (nyíl)

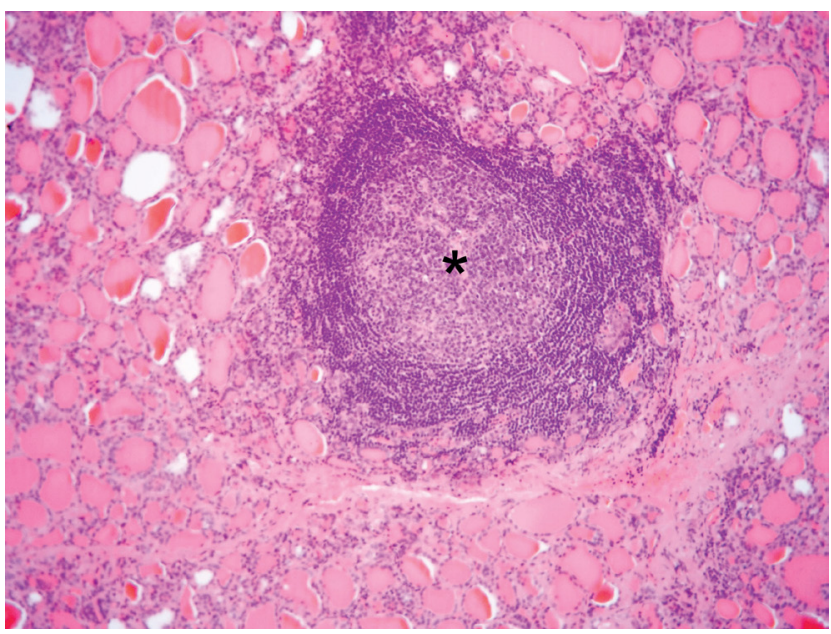

3/B ábra

A pajzsmirigy jobb oldali lebenyének részlete, mikroszkópos kép. A változatos tág, enyhe hyperplasia jeleit mutató folliculusok között chronicus lymphocytás beszűrődés és nyiroktüszó ismerhető fel (csillag jelzi, HE, ×200)

vizsgálatával. Fluoreszcens in situ hibridizációval (FISH) a daganatban MDM2-amplifikáció nem volt azonosítható. A mütét után szcintigráfiás vizsgálatot végezve a nyak vetületében 3 darab, körülbelül 10 mm-es halmozás volt látható. Két alkalommal került sor ablatiós célú radiojódkezelésre a Nukleáris Medicina Osztályon, utóbbi alkalommal alfa-tireotropin-stimulációt követően. A mútét és az izotópterápiák után fokozatos levotiroxinszubsztitúciós dózisemelésre kényszerültünk, a korábbi 100 ugrról napi 200 ugr-ra.

\section{Megbeszélés}

Zsírszövet jelenléte gyakran megfigyelhető olyan szervben, ahol a parenchyma sorvadásos folyamata is megindul, így leírták a thymusban, a mellékpajzsmirigyekben, a nyálmirigyekben, a pancreasban és az emlöben egyaránt [7]. Kórbonctani vizsgálatok mutatják, hogy a

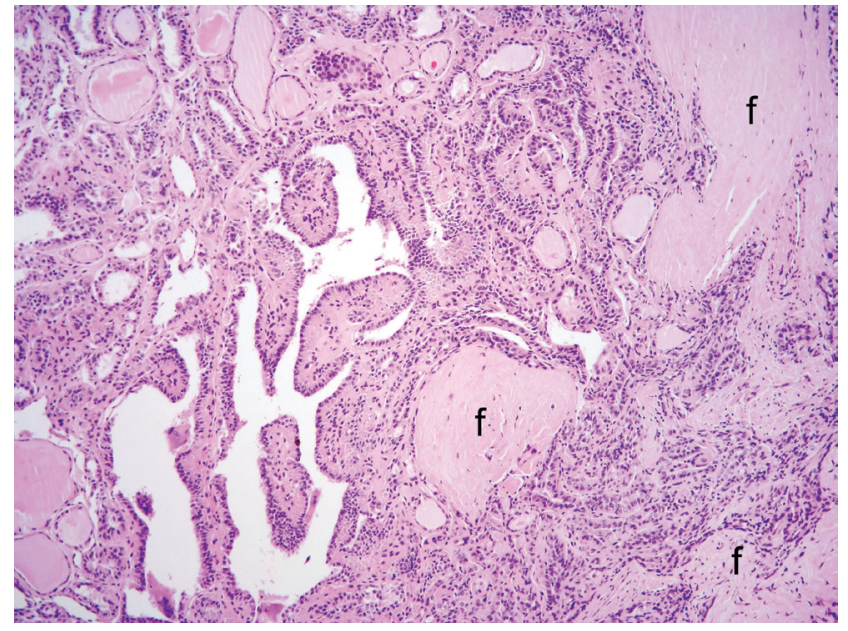
\begin{tabular}{l|l} 
3/C ábra & $\begin{array}{l}\text { Szklerotizáló papillaris carcinoma részlete, fokozott fibrosis (f) } \\
\text { jeleivel }(\mathrm{HE}, \times 200)\end{array}$
\end{tabular}

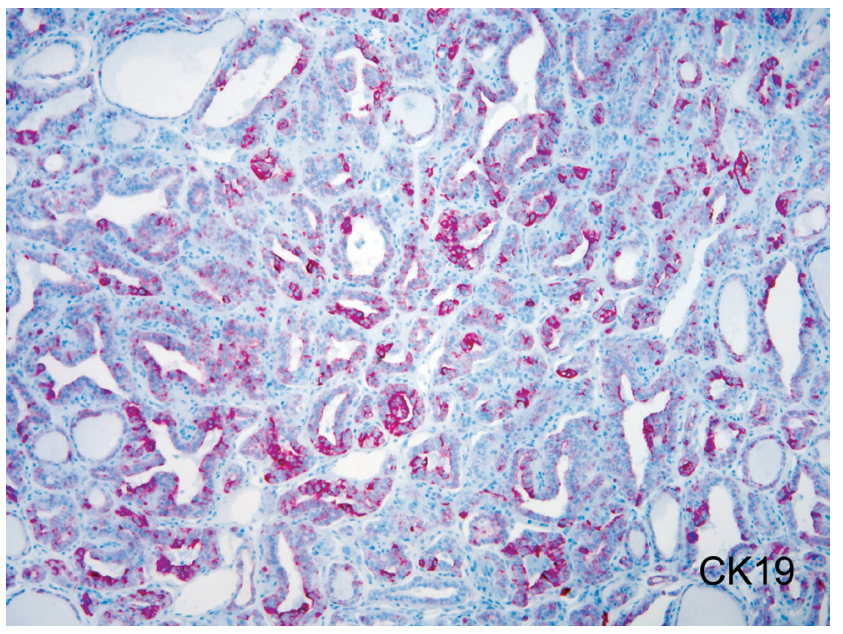

3/D ábra | A daganatsejtekben expresszálódó CK19 pozitív festődését a barnásvörös reakciótermék jelzi (indirekt immunhisztokémia, hematoxilin-magfestés, $\times 200$ )

pajzsmirigyben extrém ritkaságnak számít a zsírszövet, mely inkább a tok alatt és az erek mentén található [8]. Zsírtartalmú elváltozás a pajzsmirigyben a) makroszkóposan érett zsírszövet, b) mikroszkóposan intracellularis zsírvacuolum, c) „clear cell” vagy „lipid-rich” adenoma lehet [9]. Az alábbi kórképekben megnövekedhet a zsírszövet mennyisége: Hashimoto-thyreoiditis, amyloid struma zsírinfiltrációval, intrathyreoidealis thymus, mellékpajzsmirigy-lipoma. Néhány malignus (enkapszulált papillaris carcinoma, liposarcoma) és benignus (adenolipoma, lipoma) pajzsmirigy-elváltozásban is leírtak zsírszaporulatot [8].

Előfordul, hogy a nyaki régióban felfedezett lipoma kísértetiesen hasonlít a pajzsmirigygöbre, különösen akkor, ha az elváltozás körbefogja a pajzsmirigyet, illetve annak állományába benő. Képalkotó (elsődlegesen komputertomográfiás [CT-]) vizsgálattal a legtöbb ilyen eset elkülöníthető [10]. 




4/A ábra

A pajzsmirigy eltávolított bal oldali lebenyében kialakult papillaris microcarcinoma mikroszkópos képe. Fokozott fibrosis (f) jeleit mutató részlet a daganatból $(\mathrm{HE}, \times 100)$

Számos differenciáldiagnosztikai nehézséggel szembesülünk, amikor zsírtartalmú pajzsmirigy-elváltozást találunk. A fó különbség a lipoma és a diffúz lipomatosis között, hogy míg az előbbi tokkal rendelkezik, az utóbbi nem [1]. Diffúz lipomatosisban a zsírszövet nem körülírtan helyezkedik el.

Extrathyreoidealisan elhelyezkedő csomók, pozitív mellékpajzsmirigy-szcintigram, citoplazmatikus glikogén jelenléte, valamint a folliculusok, tiroxin és tireoglobulin hiánya esetén gondoljunk mellékpajzsmirigy-lipomára $[4,11]$. Immunhisztokémiailag tireoglobulinpozitív esetek viszont megerösítik a pajzsmirigy eredetet [12].

$\mathrm{Az}$ adenolipoma és az amyloid struma közti differenciálás az utóbbiban jelen lévő, kristályibolyával és kongóvörössel megfesthető amyloid depozitumokkal történik, továbbá a betegséghez szisztémás amyloidosis társul. Lymphocytás thyreoiditisben a kötőszövet diffúz lymphocytás infiltrációja látható. A liposarcoma egy agreszszív, gyors növekedésû tumor $[13,14]$. Lipid-rich adenomában a folliculusokban lévő zsírsejteket polarizációs mikroszkóppal vizsgálva kettős fénytörést mutató lipidkristályokat lehet kimutatni. Egyes vélemények szerint a lipidekben gazdag folliculussejtek metaplasztikus transzformáció következményei [15]. Mások a különböző lipidfrakciók vékonyréteg-kromatográfiás vizsgálattal történő elkülönítésével arra a következtetésre jutottak, hogy

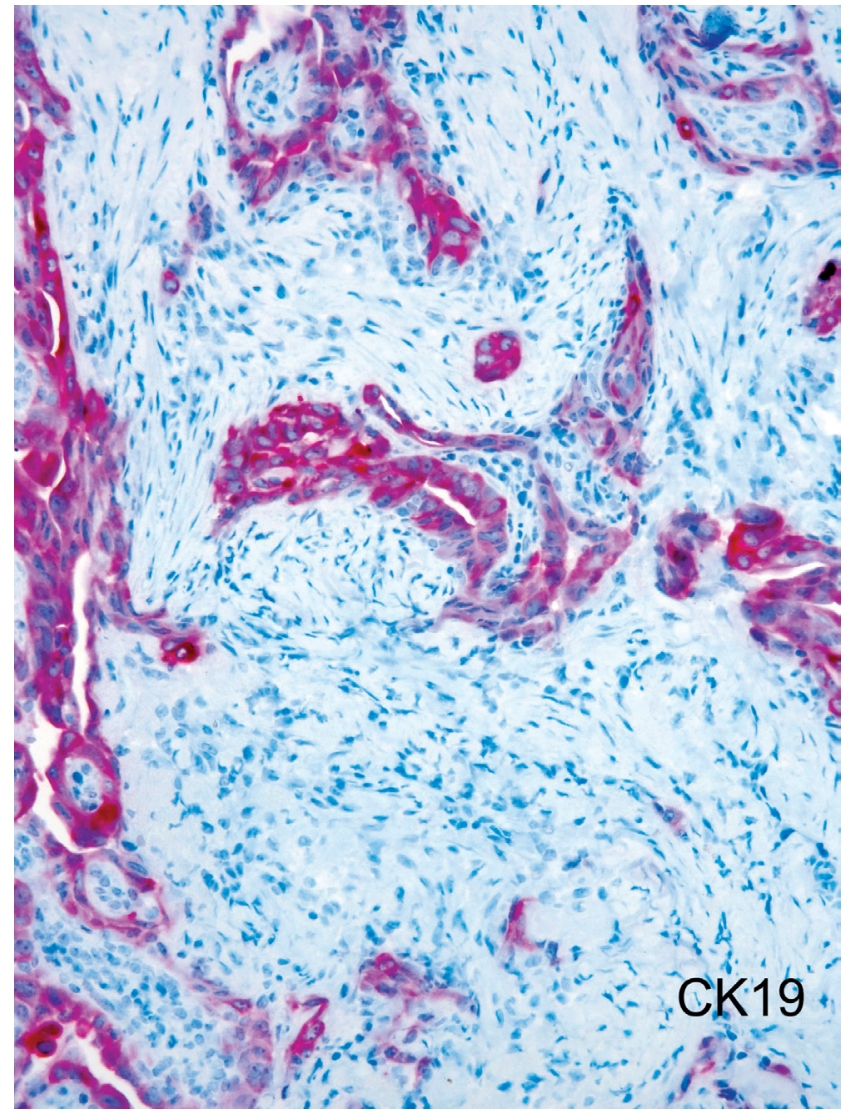

4/B ábra

A daganatsejtekben expresszálódó CK19 pozitív festődését a barnásvörös reakciótermék jelzi (indirekt immunhisztokémia, hematoxilin-magfestés, $\times 200$ )

az egyes lipid-alkotóelemek változó szöveti eloszlását a különböző intracellularis lipidmetabolizmusok következményének lehet tekinteni [16]. A papillaris carcinoma klasszikus formája papillaris szerkezetet mutató tumorsejtképződményekből áll, melyekhez follicularis elemek társulhatnak. Gyakoriak a psammomatestek, a lymphocytás infiltráció és a többgócúság [17, 18].

A thyreolipoma - progresszív növekedése esetén - a légutakat és a felső gastrointestinumot komprimálva dyspnoét, dysphagiát és rekedtséget okozhat. A legtöbb esetben - a pajzsmirigy-hormonfunkciók alapján - a beteg euthyreoticus, azonban néhány közleményben hyper-, illetve hypothyreosisról is beszámoltak. A tumor növekedési üteme és mérete alapján a szintén gyorsan növekvő anaplasticus carcinomát és a pajzsmirigylymphomát kell elkülöníteni.

A radiológiai vizsgálatok nem karakterisztikusak a diagnózis felállításában [19]. Az ultrahang, a CT és a mágnesesrezonancia-vizsgálat (MRI) makroszkópos méretű zsírtartalmú elváltozásokat tud kimutatni [3]. Ultrahangvizsgálat során a zsírszöveti infiltrációk vagy zsírtömegek izoechogének lehetnek, így elkülönítésük a normálpajzsmirigytől nehézségekbe ütközik. CT-vizsgálat során a zsírszövetre jellemző negatív denzitás (-30 és -40 közötti Hounsfield-egység [HU]) informatív [8]. A mellkasi-nyaki CT-vizsgálatok során incidentálisan ta- 
lált, zsírszövetre jellemző HU denzitású, pajzsmirigyen belüli jól körülhatárolt képletek prevalenciája a földrajzi elhelyezkedéstől, etnikai csoporttól függően $0,98 \%$ és 1,2\% közöttinek adódott. Más közlemények 2,8\%-ról számolnak be [20]. Ezen tanulmányok $10 \mathrm{~mm}$ alatt teendőt nem írnak le, míg $15 \mathrm{~mm}$ felett évente ultrahangos követést javasolnak az esetleges malignizálódás kiszűrésére. Az utóbbi esetben rapid növekedés, lymphadenopathia, infiltratív megjelenés és a CT során a denzitás $>50$ HU figyelhető meg. A tumor növekedése elérheti a felső mediastinumot és a retropharyngealis compartmenteket, következményes kompressziót vagy diszlokációt okozva a légutakban és a vascularis struktúrákban.

Kim és mtsai 1205 beteg nyaki CT-felvételét elemezték retrospektív tanulmányukban, melynek során 1,2\%ban találtak intrathyreoidealisan elhelyezkedő zsírtartalmú elváltozásokat alacsony denzitással. A legtöbb ilyen elváltozás extrathyreoidealis zsírral állt összeköttetésben az úgynevezett „fatty band”-en (zsíros köteg) keresztül, és „scoop sign” (merőkanál) képét utánozva leginkább fejlődési rendellenességként fogható fel, mely az embriogenezis alatti migráció teóriáját támasztaná alá [21].

$\mathrm{Az}$ adenolipoma preoperatív diagnózisában hasznos lehet az FNA-citológia [3, 22], tekintve, hogy a normál follicularis sejtek között zsírsejtek jelenlétét tudja kimutatni. Bár nincs olyan guideline, mely megalapozná a thyreolipoma FNA-diagnózisát, mégis ezzel a módszerrel ki lehet zárni az anaplasticus carcinomát és a lymphomát.

Esetünkben az adenolipomán kívül a pajzsmirigylebenyek szövettani vizsgálatával Hashimoto-thyreoiditist és multifocalis papillaris carcinomát is igazoltunk. Megemlítendő, hogy az FNA-citológiai vizsgálat kizárólag a pajzsmirigyről lefüződött terimére szorítkozott, mivel az ultrahanggal a pajzsmirigy lebenyeiben kicsiny $(5$, illetve 6 mm-es) göböket verifikáltak. Csak a mütét során elvégzett, a pajzsmirigy fagyasztásos és posztoperatív szövettani vizsgálatai egyértelműsítették a malignus elváltozást.

Tekintettel arra, hogy az aegrota korábbi gondozása háziorvosi, illetve diabetológiai ellátás keretében történt, retrospektíven tudtuk összegyüjteni a klinikai adatokat. Kiderült, hogy a szülést követően néhány hónappal alakult ki a manifeszt hypothyreosis, mely ekkortól folyamatos szubsztitúciós kezelést igényelt. Ismerve a mútétkori és a 20 évvel korábbi kiindulási klinikai állapotot, minden bizonnyal a folyamat post partum thyreoiditisként fellángolva került felismerésre az alapellátásban, majd chronicus lymphocytás (Hashimoto-) thyreoiditis alakult ki az évek során. Az utóbbit alátámasztja az ultrahangkép, a szövettani vizsgálat, az emelkedett anti-TPOtiter, valamint a betegség kórlefolyása. Differenciáldiagnosztikai szempontból meg kell említeni a ritka előfordulású, immunglobulin-4-nek (IgG4) tulajdonított Riedel-thyreoiditist, mely szintén a chronicus lymphocytás thyreoiditis egyik variánsának tekinthető, itt azonban a fibrosis uralja a képet, és a pajzsmirigy tömött, kemény tapintatú, ezért struma lignosának is nevezik. Megemlítendő, hogy ez a szisztémás betegség más, egyéb gyulladásos betegséggel gyakran társul az emelkedett IgG4-szint következtében [17]. Kizárandó még az atrophiás thyreoiditis, mely a gyulladásos folyamat „kiégett” végső állapotának tekintendő, amikor a pajzsmirigy elsorvad, és az ultrahangvizsgálat során is csak alig látható, heges területet lehet vizualizálni. Esetünkben ez utóbbi két kórkép egyértelmúen kizárható volt a tapintási lelet, az ultrahangkép és az elvégzett szövettani vizsgálatok alapján. Megemlítendő, hogy az anti-TPO, a TSH és a perifériás pajzsmirigyhormonok időbeli monitorozására, dinamikájának vizsgálatára sem volt lehetőségünk, hiszen a gestatiós időszakban és az ezt követő 20 évben sem állt a beteg endokrinológiai gondozás alatt.

Fontosnak tartjuk kiemelni a trimeszterspecifikus pajzsmirigyhormon-értékeknek megfeleló és a post partum időszak gondozási feladatait, ezek ismertetése azonban messze túlmutatna a jelen esettanulmányunk keretein. Megemlítendő egy adat - mely az Amerikai Pajzsmirigy Társaság ajánlásában szerepel -, miszerint a post partum thyreoiditises anyák 54\%-ában tartósan perzisztál a hypothyreoticus fázis az első év végén is [23]. Más tanulmányok 30-50\%-ban határozzák meg az elkövetkezendő 10 évben a manifeszt hypothyreosis kialakulását, különösen azon anyákban, akiknél antitestek mutathatók ki [24]. A kutatások bizonyították, hogy a thyreocyták károsodása komplex, többlépcsős folyamatnak tekinthető, amelyben számos faktor: immunológiai, immungenetikai, epigenetikai és környezeti tényező egyaránt szerepet játszik [25].

Esetünkben a pajzsmirigybetegség kialakulása a terhesség alatti immunszuppresszió szülést követő felerősödésével, az emelkedett anti-TPO-szinttel, az elhízással és a szénhidrát-anyagcsere felborulásával egyaránt összefüggésbe hozható [26].

Autoimmun eredetü endokrin megbetegedés esetén mindig kell más endokrin kórképre (az autoimmun poliendokrin szindrómákra) is gondolni, így a legfontosabb kizárandó kórképek az Addison-kór, az autoimmun diabetes mellitus, a vitiligo, az anaemia perniciosa, a coeliakia, a candidiasis, a hypoparathyerosis, a hypogonadismus és az autoimmun hepatitis [26, 27].

Számos tanulmányban vizsgálták a Hashimoto-thyreoiditis és a papillaris carcinoma együttes előfordulását. Resende de Paiva és mtsai által 2017-ben megjelent közleményben egy szisztematikus irodalomkutatás eredménye került bemutatásra. Az 1955 és 2016 között megjelent, 64628 beteget felölelő, 36 tanulmány eredményeit összefoglaló munkában szignifikáns összefüggést találtak a papillaris carcinoma és a Hashimoto-thyreoiditis, valamint a pajzsmirigylymphoma és a Hashimoto-thyreoiditis relatív rizikója között. A malignus transzformációért a chronicus gyulladásos folyamatban szereplő immunsejtek által termelt cellularis mediátorok, valamint az emelkedett TSH stimulálta follicularis epithelialis proliferáció tehető felelőssé. A levotiroxinszubsztitúciós kezeléssel elért TSH-szint-csökkentés egyúttal jelentősen csökkenti a pajzsmirigy-carcinomák kialakulását. A patogenezisben 
számos genetikai abnormitás érintett: RET/PTC átrendeződés, p63-protein-expresszió, BRAF-mutáció, PI3K/Akt jelátvitel $[18,28]$. Egyes iskolák úgy tartják, hogy a RET-onkogének átrendeződése egy specifikus markere is lehetne a korai stádiumú pajzsmirigy-carcinomának. Mdm2-gén expresszióját zsírszövetet tartalmazó daganatokban vizsgálva azt találták, hogy ez kapcsolatban állhat a tumor progressziójával, például liposarcomában [29].

Kevés olyan tanulmány, adat létezik, mely a Hashimoto-thyreoiditis és a papillaris carcinoma időbeliségét meghatározná egyazon betegben, azaz hogy egyik vagy másik kórkép volt-e előbb, vagy szimultán történt a felfedezésük. Egyéb pajzsmirigycarcinoma-altípus (például follicularis, medullaris, anaplasticus carcinoma) és a Hashimotothyreoiditis között nem találtak szignifikáns összefüggést, azonban az adatok limitáltan állnak rendelkezésre.

Dong és mtsai 808, Hashimoto-thyreoiditises és unifocalis vagy multifocalis papillaris carcinomában szenvedő beteget retrospektíven elemeztek a rendelkezésre álló szövettani eredmények és preoperatív laboratóriumi eredmények alapján. Azon csoportban, ahol a Hashimoto-thyreoiditis és a multifocalis papillaris carcinoma együttesen fordult elő, a betegek $84 \%$-ában észleltek jelentősen emelkedett antitesttitert (anti-TPO>1300 IU/ $\mathrm{ml}$ ), ugyanakkor az unifocalis papillaris carcinomás és/ vagy Hashimoto-thyreoiditises csoportban nem találtak az előbbihez fogható anti-TPO-szint-emelkedést [30].

$\mathrm{Az}$ északkelet-magyarországi régióban történt felmérés során azt találták, hogy a papillaris carcinoma lényegesen gyakrabban bizonyult multifocalisnak Hashimotothyreoiditisben, mint nélküle [31].

Az Amerikai Pajzsmirigy Társaság ajánlása szerint azon betegeknél, akik >10 mm-es pajzsmirigy-carcinomával rendelkeznek, a sebészi kezelést kell választani, mely lehet közel totális vagy totális thyreoidectomia, kivéve, ha a mütétnek kontraindikációja áll fenn. Jelen esetünkben totális thyreoidectomia történt a kétoldali papillaris carcinoma és a növekedést mutató adenolipoma együttes jelenléte miatt.

A pajzsmirigyben lévő zsírszövet megjelenésével kapcsolatosan számos vélemény látott napvilágot, azonban a pontos okot nem ismerjük. A szerzők által leginkább elfogadott teória szerint ez egy fejlődési rendellenesség, miszerint az embriogenezis során zsírszöveti szigetek kerülhetnek a pajzsmirigy állományába a kötőszövetes tok kialakulása előtt, a harántcsíkolt izom inclusióihoz hasonlóan. A diffúz lipomatosissal nem járó egyéb tumorokban a zsírszövet jelenlétét sokan a tumor neoplasticus komponensének tartják, így kevert daganatról beszélnek. Mások a metaplasticus teóriának a hívei, miszerint vascularis változások, következményes chronicus szöveti hypoxia vagy senilis involutio okozná a kötőszöveti fibroblastok metaplasiáját. Ez magyarázná a zsír jelenlétét az amyloid strumában is $[1,4-8,14]$.

Trites közleményében bemutat egy olyan thyreolipomás beteget, akinél thymolipoma és pharyngealis lipoma szimultán jelen van, ami azt sugallja, hogy különböző behatásokra a primitív előbél rendellenes irányban fejlődött a korai embriogenezis során [32]. Véleményünk szerint a thyreolipomát leginkább egy hyperplasiás, kevert epithelialis és mesenchymalis elemeket tartalmazó benignus tumorként lehetne jellemezni. Kevésbé valószínű a zsírszövet mesenchymalis metaplasiás eredete; ezt támasztaná alá, hogy fibrosis, gyulladásos eltérések és következményes regresszív elváltozások nem mutathatók ki, mint például a cysticus fibrosis esetén.

\section{Következtetések}

Esetismertetésünk során bemutattunk egy 52 éves női cukorbeteget, aki a pajzsmirigy egy igen ritka daganatával rendelkezett. Az elváltozás szokatlan elhelyezkedése, továbbá az aegrota klinikuma miatt számos nehézségbe ütköztünk a kivizsgálás során. A végső diagnózishoz csak a sebészi eltávolítás és a göbös pajzsmirigy fagyasztásos, majd hisztopatológiai vizsgálata során jutottunk el. Lefüződött nyaki thyreolipoma mellett Hashimoto-thyreoiditist és kétoldali papillaris carcinomát találtunk, így totális thyreoidectomia történt, I131-izotóp-terápiával kiegészítve a kezelést.

Az ilyen és a hasonló esetek kapcsán számos klinikai, differenciáldiagnosztikai, fejlődéstani és terápiás nehézséggel szembesülhetünk. Ezért is tartjuk fontosnak a nyaki terimék alapos obszervációját, eredetük tisztázását és az elvégzett képalkotó vizsgálatok után - növekedésük esetén - azok sebészi eltávolítását és további gondos hisztopatológiai vizsgálatát. Esetismertetésünkben egy szokatlan radiológiai megjelenést mutató ritka elváltozásra (thyreolipoma) fókuszáltunk, mely mellett ugyanazon szerv más területén megbúvó malignus elváltozást is találtunk. Ez felhívja a vizsgálók figyelmét a malignus transzformáció lehetőségére, melyre még az irányelvek követése mellett is mindig gondolni kell.

Anyagi támogatás: A közlemény megírása anyagi támogatásban nem részesült.

Szerzôi munkamegosztás: S. T.: A klinikum összefoglalása. A beteg adatainak összeállítása, a közlemény megírása. P. I.: A hisztopatológiai vizsgálat elvégzése, értékelése. Aktív részvétel az irodalomkutatásban, a kézirat létrejöttében, szerkesztésében. A kollégák munkájának összefogása. P. P.: A citopatológiai vizsgálat elvégzése, értékelése. L. A.: Részvétel a hisztopatológiai vizsgálatokban. S. Zs.: A molekuláris patológiai vizsgálat elvégzése, értékelése. T. M.: Részvétel a nukleáris diagnosztikában és a radioaktív jódos kezelésben. K. P.: A nyaki sebészeti mütét elvégzése. A cikk végleges változatát valamennyi szerző elolvasta és jóváhagyta.

Érdekeltségek: A szerzőknek a cikk megírásával kapcsolatosan nincsenek érdekeltségeik. 


\section{Köszönetnyilvánítás}

A szerző́k köszönetet mondanak Kónya Miklósnak (Országos Onkológiai Intézet, Budapest) a patológiai anyagok minőségi fotózásáért, Balogh Emese Emőkének (ARTMEDX Egészségügyi Szolgáltató Kft., Budapest) a betegnek a vizsgálatokra, kezelésekre történő felkészítéséért, és mindazon munkatársaknak, akik a beteg laboratóriumi, képalkotó és egyéb vizsgálataiban, valamint a mútétje során közremúködtek.

\section{Irodalom}

[1] Sanuvada RV, Chowhan AM, Rukmangadha N, et al. Thyrolipomatosis: an inquisitive rare entity. Gland Surg. 2014; 3: E6-E9.

[2] Kitagawa W, Kameyama K, Tamai S, et al. Adenolipoma of the thyroid gland: report of a case. Surg Today 2004; 34: 593-596.

[3] Borges A, Catarino A. Case 53: adenolipoma of the thyroid gland. Radiology 2002; 225: 746-750.

[4] Gonda G, Sápi Z, Tóth L. Adenolipoma of the thyroid gland. [A pajzsmirigy adenolipomája.] Magy Onkol. 1991; 35: 169-171. [Hungarian]

[5] Hun-Soo K, Ki-Jung Y. Adenolipoma of the thyroid gland: report of a case with diagnosis by fine-needle aspiration cytology. Diagn Cytopathol. 2008; 36: 253-256.

[6] Gupta A, Mathur SK, Batra C, et al. Adenolipoma of the thyroid gland. Indian J Pathol Microbiol. 2008; 51: 521-522.

[7] Schröder S, Böcker W, Hüsselmann H, et al. Adenolipoma (thyrolipoma) of the thyroid gland. Report of two cases and review of literature. Virchows Arch A Pathol Anat Histopathol. 1984; 404: 99-103.

[8] Bell S, Sosa GA, del Valle Jaen A, et al. Thyroid lipomatosis in a 36-year-old patient with rheumatoid arthritis and a kidney transplant. Endocrinol Diabetes Metab Case Rep. 2016; 2016: 160007.

[9] LiVolsi VA. Unusual tumors and tumor-like conditions of the thyroid. In: LiVolsi VA. (ed.) Surgical pathology of the thyroid. Major problems in pathology series. Saunders, Philadelphia, PA, 1990; pp. 323-350

[10] Leonidas JR, Goldman JM, Wheeler MF. Cervical lipomas masquerading as thyroid nodules. JAMA 1985; 253: 1436-1437.

[11] Ge Y, Luna MA, Cowan DF, et al. Thyrolipoma and thyrolipomatosis: 5 case reports and historical review of the literature. Ann Diagn Pathol. 2009; 13: 384-389.

[12] Sheikh SS, Massloom HS. Lipoadenoma: is it arising from thyroid or parathyroid? A diagnostic dilemma. ORL J Otorhinolaryngol Relat Spec. 2002; 64: 448-450.

[13] Nandyala HS, Madapuram S, Yadav M, et al. Diffuse lipomatosis of the thyroid gland with papillary microcarcinoma: Report of a rare entity. Indian J Pathol Microbiol. 2015; 58: 348-350.

[14] Gupta R, Arora R, Sharma A, et al. Diffuse lipomatosis of the thyroid gland: a pathologic curiosity. Indian J Pathol Microbiol. 2009; 52: 215-216

[15] Schröder S, Hüsselmann H, Böcker W. Lipid-rich cell adenoma of the thyroid gland. Report of a peculiar thyroid tumour. Virchows Arch A Pathol Anat Histopathol. 1984; 404: 105-108.

[16] Tóth K, Péter I, Kremmer T, et al. Lipid-rich cell thyroid adenoma: histopathology with comparative lipid analysis. Virchows Arch A Pathol Anat Histopathol. 1990; 417: 273-276.

[17] Nagy E. Thyroiditis. In: Lakatos P, Takács I. (eds.) Thyroid diseases in the medical practise. [Thyreoiditisek. In: Lakatos P,
Takács I. (szerk.) Pajzsmirigybetegségek az orvosi gyakorlatban.] SpringMed, Budapest, 2017; pp. 128-135. [Hungarian]

[18] Konrády A. Papillary thyroid carcinoma. In: Lakatos P, Takács I. (eds.) Thyroid diseases in the medical practise. [Papilláris pajzsmirigy-carcinoma. In: Lakatos P, Takács I. (szerk.) Pajzsmirigybetegségek az orvosi gyakorlatban.] SpringMed, Budapest, 2017; pp. 139-142. [Hungarian]

[19] Gamra OB, Romdhane N, Nefzaoui S, et al. Diffuse lipomatosis of the thyroid gland. Case Report. Egyptian J Ear, Nose, Throat Allied Sciences 2016; 17: 167-169.

[20] Gossner J. Thyrolipomas - Prevalence in computed tomography and suggestions for pragmatic management. Pol J Radiol. 2015; 80: 305-308.

[21] Kim KH, Seo HS, Lee YH, et al. Study of intrathyroid fat-containing lesions using CT imaging with literature review. Neuroradiology 2013; 55: 1405-1411.

[22] Demirpolat G, Guney B, Savas R, et al. Radiologic and cytologic findings in a case of thyrolipoma. AJNR Am J Neuroradiol. 2002; 23: 1640-1641.

[23] Stagnaro-Green A, Abalovich M, Alexander E, et al. Guidelines of the American Thyroid Association for the diagnosis and management of thyroid disease during pregnancy and postpartum. Thyroid 2011; 21: 1081-1125.

[24] Speer G. The impact of thyroid function in women at the reproductive age: infertility, pregnancy and the postpartum period. [A pajzsmirigymúködés jelentősége fertilis korú nőkben: meddőség, terhesség és a post partum időszak.] Orv Hetil. 2013; 154: 2017-2023. [Hungarian]

[25] Balázs Cs. Hashimoto's thyroiditis, the model of organ-specific autoimmune disorders. [A Hashimoto-thyreoiditis a szervspecifikus autoimmun endocrinopathiák típusos formája.] Orv Hetil. 2007; 148(Suppl 1): 31-33. [Hungarian]

[26] Reismann P, Somogyi A. Diabetes and thyroid disorders. [Cukorbetegség és pajzsmirigybetegségek.] Orv Hetil. 2011; 152: 516-519. [Hungarian]

[27] Balázs Cs, Fehér J. Associations of autoimmune disorders in endocrine diseases. [Autoimmun endokrin kórképek társulásai.] Orv Hetil. 2009; 150: 1589-1597. [Hungarian]

[28] Resende de Paiva C, Grønhøj C, Feldt-Rasmussen U, et al. Association between Hashimoto's thyroiditis and thyroid cancer in 64,628 patients. Front Oncol. 2017; 7: 53.

[29] Tuna B, Lebe B, Sis B, et al. Mdm2 gene expression in adiposetissue tumors: association with tumor progression in liposarcomas. APJ 2004; 1: 11-18.

[30] Dong S, Xia Q, Wu YJ. High TPOAb levels (>1300 IU $/ \mathrm{mL}$ ) indicate multifocal PTC in Hashimoto's thyroiditis patients and support total thyroidectomy. Otolaryngol Head Neck Surg. 2015; 153: 20-26.

[31] Molnár S, Győry F, Nagy E, et al. Clinico-pathological features of papillary thyroid cancer coexistent with Hashimoto's thyroiditis. [A Hashimoto-thyreoiditisben kialakuló papillaris pajzsmirigy-carcinoma klinikopatológiai jellegzetességei.] Orv Hetil. 2017; 158: 178-182. [Hungarian]

[32] Trites AE. Thyrolipoma, thymolipoma, and pharyngeal lipoma: a syndrome. Can Med Assoc J. 1966; 95: 1254-1259.

(Steiner Tamás dr., Budapest, Edömér utca 4., 1113 e-mail: artmedx@freemail.hu) 